\title{
Posttraumatic Syringomyelia: A Technical Note
}

\author{
Travma Sonrast Siringomiyeli: Teknik Not
}

\author{
Ali Fahir OZER ${ }^{1}$, Hosein Jafari MARANDI ${ }^{2}$, Mehdi SASANI², Tunc OKTENOGLU², Tuncer SUZER ${ }^{2}$ \\ ${ }^{1}$ Koc University, School of Medicine, Department of Neurosurgery, Istanbul, Turkey \\ ${ }^{2}$ American Hospital, Department of Neurosurgery, Istanbul, Turkey
}

Corresponding Author: Ali Fahir OZER / E-mail: alifahirozer@gmail.com

\begin{abstract}
AIM: Previous studies have not identified a preferred surgical technique to treat posttraumatic syringomyelia. Both syringopleural shunting and arachnoidolysis are used in neurosurgery practice for the surgical treatment of posttraumatic syringomyelia. In this study, we present a new technique designed to achieve a better outcome following surgery.

MATERIAL and METHODS: A 33-year-old man, who exhibited pain and spasticity below the thoracic region after a traffic accident that occurred 16 years ago, was treated with a new technique. He also had paraparesis and urinary incontinency before the surgery. The initial cervicothoracic Magnetic Resonance Imaging (MRI) scans showed the development of a syrinx in the T4-5 region. A syringopleural shunt and bilateral subarachnoid to subarachnoid catheters from proximal to distal zones of the syrinx were performed under surgical microscope.

RESULTS: The operative time was 90 minutes, and the blood loss was approximately $100 \mathrm{~mL}$. The patient was mobilized on postoperative day 2 and was discharged 4 days after surgery with mild improvement of his preoperative symptoms. Postoperative MRI scans revealed partial regression at 6 months and complete decompression of the syrinx at 3 years follow-up without any clinical symptoms.
\end{abstract}

CONCLUSION: This is a report of minimal-access insertion combining syringopleural with subarachnoid-subarachnoid bypass shunt insertion. This minimally invasive technique seems to be an effective and safe method.

KEYWORDS: Posttraumatic syringomyelia, Shunt surgery, Magnetic resonance imaging, Subarachnoid-subarachnoid bypass, Cervical spinal cord

öz

AMAÇ: Travma sonrasında ortaya çıkan siringomiyeli tedavisinde tercih edilmesi gereken bir cerrahi teknik tarif edilmemiştir. Siringoplevral şant ve araknoidolizis halen nöroşirürji pratiğinde kullanılmaktadır. Bu çalışmada, cerrahi sonrası daha iyi sonuç elde etmek için kullandığımız yeni bir tekniği tarif etmekteyiz.

YÖNTEM ve GEREÇLER: On altı sene önce trafik kazası geçiren, torakal bölge altında ağrı, spastisite, paraparezi ve inkontinans şikayetleri olan, 33 yaşında erkek hasta bu yeni teknik ile ameliyat edildi. Manyetik Rezonans Görüntüleme (MRG) incelemesinde T4-5 seviyesinde sirinks saptandı. Hastaya mikroşirürjikal teknikler kullanılarak siringoplevral şant ve bilateral proksimal ve distal subaraknoid mesafeler arasına kateter yerleştirilmesi ameliyatı yapıldı.

BULGULAR: Cerrahi girişim 90 dakika sürdü ve yaklaşık100 ml kan kaybı saptandı. Hasta ameliyattan sonra 2. gün mobilize edildi ve 4. gün şikayetlerinde kısmi düzelme ile taburcu edildi. Ameliyat sonrası 6 . ayda yapılan MRG ile sirinkste kısmi düzelme, 3 yıl sonra kontrolde ise hem sirinks hem de klinik tabloda tam düzelme saptandı.

SONUÇ: Bu yazıda, minimal yaklaşım ile siringoplevral ve subarkanoid-subaraknoid şant cerrahisinin kombine kullanımı rapor edilmiştir. Minimal invazif bu yöntem etkin ve güvenlidir.

ANAHTAR SÖZCÜKLER: Travma sonrası siringomiyeli, Şant cerrahisi, Manyetik rezonans görüntüleme, Subaraknoid-subaraknoid bypass, Servikal spinal kord

\section{INTRODUCTION}

Syringomyelia is a disorder that is characterized by the development of an abnormal fluid-filled cyst (syrinx) in the spinal cord, which causes progressive neurologic symptoms as it expands (13).

Posttraumatic syringomyelia is one of the causes of delayed neurological deterioration in patients with spinal cord injuries (5). The prevalence of symptomatic posttraumatic syringomyelia (PTS) is approximately $4 \%$ among patients with spinal cord injuries, whereas the prevalence of asymptomatic PTS is approximately $28 \%(1,8)$.
No standard procedure for treating syringomyelia has been established, as both shunting and arachnoidolysis are used in neurosurgery practice to treat syringomyelia $(7,9)$.

All theories to explain syrinx formation and extension have focused on cerebrospinal fluid (CSF) circulation and its disturbance as the origin of PTS (5). Surgical management is indicated in patients with progressive neurological deterioration. Treatment procedures may attempt to reestablish normal CSF circulation around the spinal cord; however, certain procedures, such as cord untethering and arachnoidolysis, are not always effective (5). In this study, we present the case of a patient with asymptomatic 
thoracic syringomyelia who was treated effectively using subarachnoid-subarachnoid and syringopleural shunts.

\section{CASE REPORT}

A 33-year-old man presented to our institution with increasing paraparesis, urinary incontinence and lower extremity pain/spasticity refractory to medical management. He had experienced lower extremity weakness and urinary problems after a car accident that occurred 16 years ago.

He underwent spinal instrumentation and fusion to treat a fourth thoracic vertebra fracture and syringopleural shunt insertion to treat cervical and thoracic syringomyelia at another institution. His neurological status was ASOA-0 (American Spinal Injury Association) for 6 months before presenting at our institution. The patient had gradually increasing back and leg pain spasticity in his lower extremities. His visual analog score for back pain was 7. Pain and temperature modalities were affected and unaffected, respectively. Thoracic MRI scans revealed a large syrinx at the T4-5 level (Figure 1).

The patient underwent surgery in prone position after the induction of general anesthesia. An incision was marked on the skin $3 \mathrm{~cm}$ in length down the midline at the T6 level, which was the location of the largest part of the syrinx, while working under microscope magnification. Bilateral hemilaminotomy and medial facetectomy were performed. Exposing the midline of the dura, a midline linear durotomy was made, and the dural edges were tented with $4 / 0$ silk suture on each side. The syrinx was entered after a myelotomy which was made using a blade no. 11. Than, a silicon catheter, (6 $\mathrm{cm}$ long, outer diameter $2.5 \mathrm{~mm}$, inner diameter $1.3 \mathrm{~mm}$ ), was prepared and inserted into the syringomyelic cavity. The proximal part of the catheter was advanced in cephalad direction of myelotomy. The distal part was introduced into the pleura, and the catheter was stitched to the pial suture.

After opening local arachnoid adhesions over the spinal cord at the side of the trauma, two silicon catheters of $6 \mathrm{~cm}$ in length were stitched on the right and left sides of the spinal cord just cranial and caudal to the lesion in the subarachnoid space. Both catheters were fixed to the inner wall of the dura mater by a $5 / 0$ silk suture bilaterally. The durotomy was closed in a running fashion with $4 / 0$ vicryl suture. The wound was closed in layers using standard methods.

The postoperative course was uneventful. The patient was followed up 1, 3, and 6 months postoperatively and then every six months for 3 years. The final neurological examination revealed that the patient could have an ordinary life. Threeand 6-year follow-up radiologic examinations revealed the decompression of the intramedullary syrinx (Figure 2, 3).

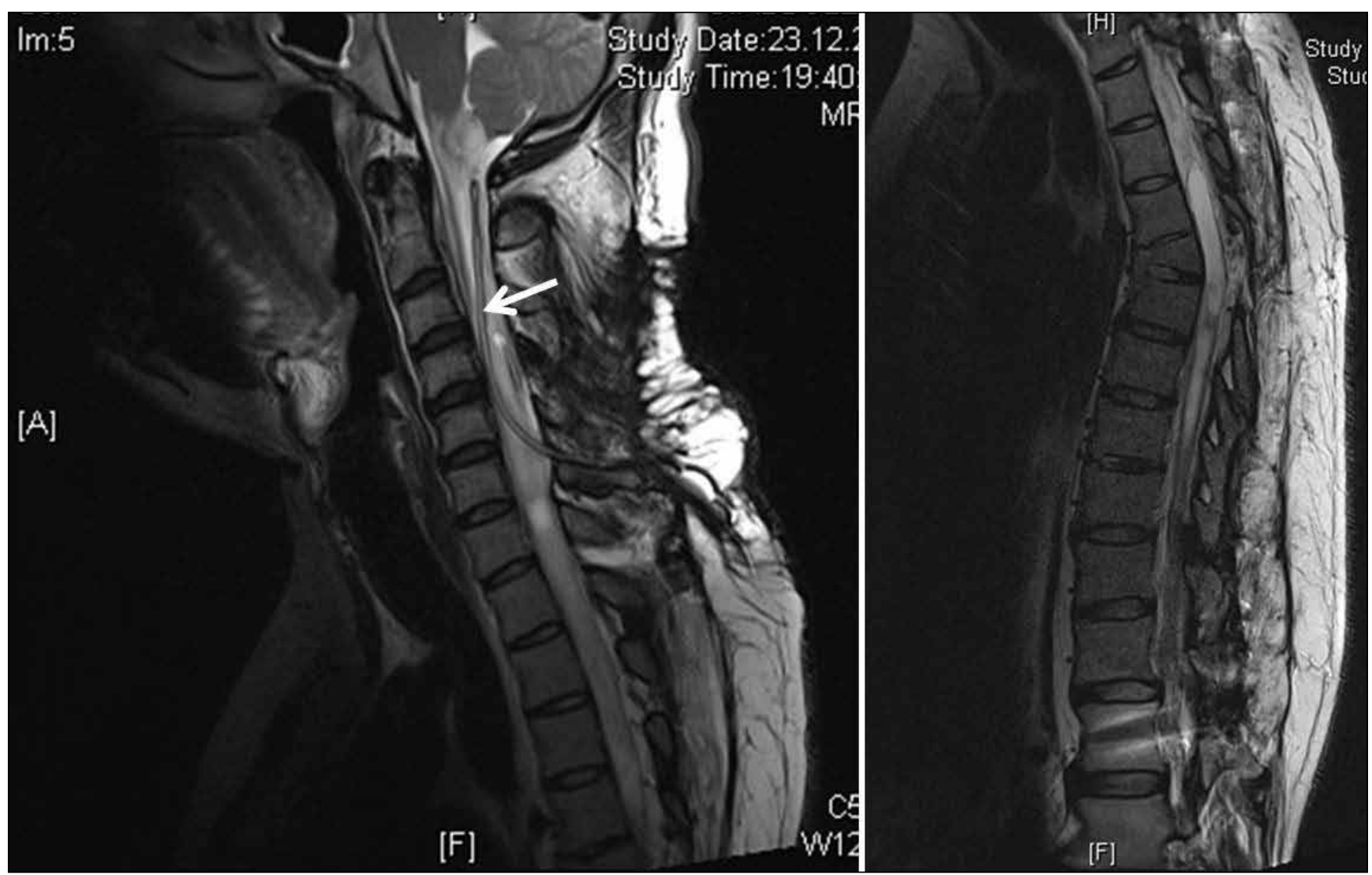

Figure 1: Preoperative sagittal MRI scans of the spine showed a large intramedullary syrinx in the cervical and thoracic regions. Adhesion was observed at the T4-5 level. A syringopleural catheter that was previously implanted is shown (white arrow). 


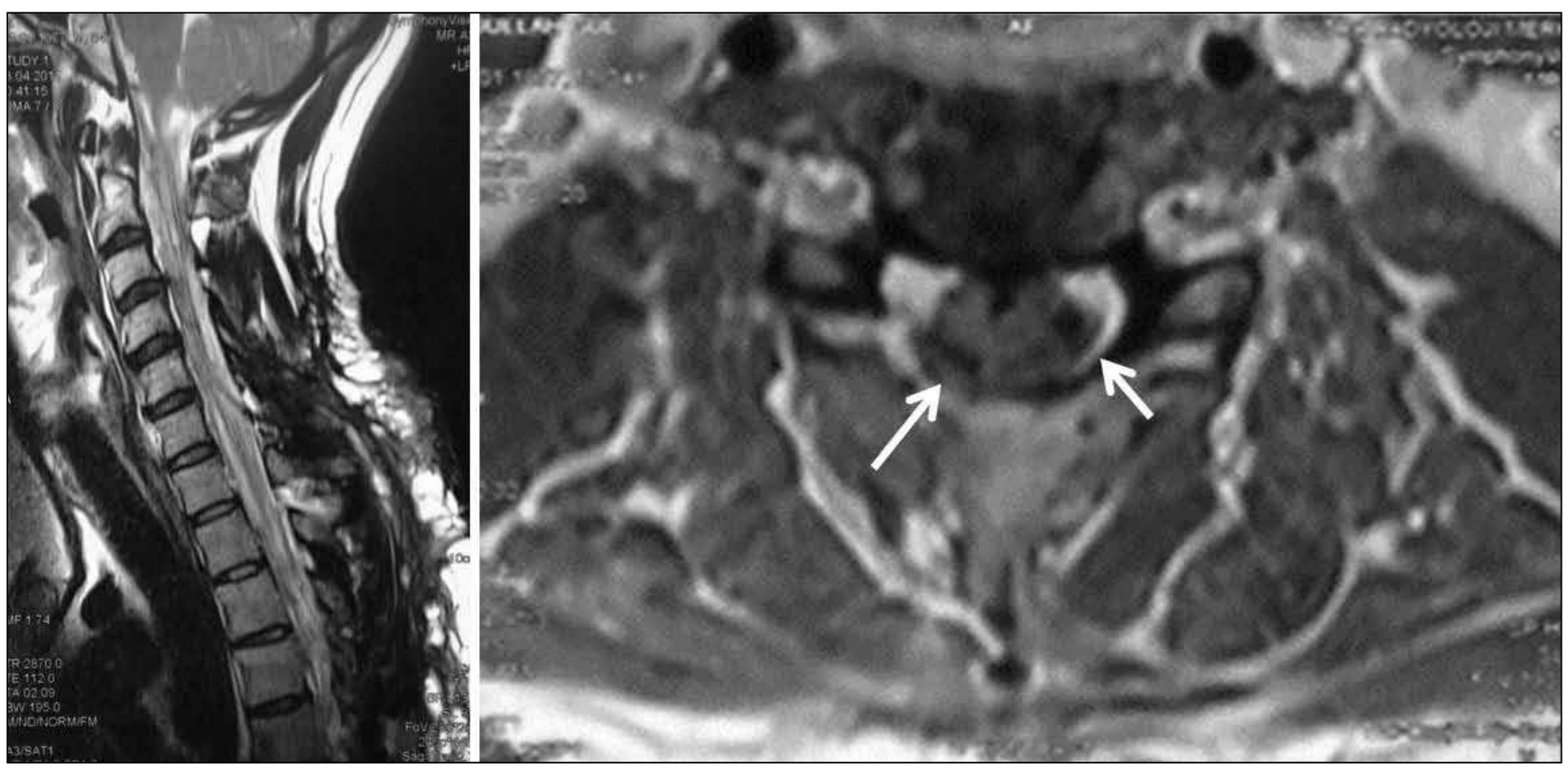

Figure 2: Six-month postoperative MRI scans show the resolution of the syrinx in the cervical and dorsal regions. An axial T1 weighted image shows the bilateral subarachnoid to subarachnoid catheters (white arrows) (Left: Sagittal; Right: Axial).



Figure 3: Three-year postoperative MRI scans disclose total regression of the intramedullary syrinx cavity. The anterior and posterior subarachnoid space is enlarged (white arrow) (Left: Sagittal; Right: Axial).

\section{DISCUSSION}

Posttraumatic syringomyelia affects approximately $28 \%$ of patients with spinal cord injuries, and current treatments are often ineffective. The natural history of the disease is variable, with approximately $1-9 \%$ of spinal cord injury patients becoming symptomatic. In $32-40 \%$ of patients with posttraumatic syringomyelia, the clinical course remains stable. In $33-43 \%$ of patients, the syrinx slowly expands, whereas rapid deterioration occurs in $21-27 \%$ of patients $(1,8)$.

To understand the underlying causes of syringomyelia, it is necessary to understand the structure and physiology of the normal spinal cord and CSF. Additionally, the structure and mechanisms of syrinx expansion (12) have been demonstrated. In syringomyelia, fluid flows diffusely and 
preferentially toward the central canal and syrinx cavity via the perivascular extracellular space. Tethering and extensive arachnoidopathy increases perioperative risks and recurrence rate (16). Levi et al. used lysis of arachnoid adhesions and expansile duraplasty to create a subarachnoid space and did not implant a draining tube (12).

In a systemic review of the literature, Bonfield et al. reported that there was no strong evidence to support the superiority of one surgical technique over the others but stated that there is a slight preference for the use of spinal cord untethering with expansile duraplasty as first-line surgical treatment (3). Tator $\mathrm{CH}$ et al. reported that the use of a syringe subarachnoid shunt is an effective method of treatment in many patients with syringomyelia (14). Klenkamp et al suggested that successful long-term management of a syrinx requires microsurgical dissection of the arachnoid scar and decompression of the subarachnoid space with a fascia lata (10).

Williams recommended that the syrinx be shunted in a lowpressure system, such as the pleural or the peritoneal cavity, for effective drainage. Furthermore, an internal posttraumatic gibbous or arachnoiditis, if present, should be dealt with at the same time. According to Williams, abolition of a pressure gradient and free flow of the cerebrospinal fluid are vital factors in minimizing the risk of recurrence of syringomyelia (15).

In an animal study, increasing caudal subarachnoid space compliance with a lumboperitoneal shunt did not affect local CSF flow into the spinal cord and syrinx. These results suggest that localized alterations in subarachnoid space compliance, rather than obstructions from traumatic arachnoiditis, may act as an important factor in syrinx pathogenesis (4).

In this study, we bypassed the upper and lower levels of the subarachnoid space at the arachnoid adhesions via silicon tubes to provide equal pressure at both sides. A review of the literature identified two theoretical studies.

Theoretical analysis of syringomyelia associated with adhesive arachnoiditis revealed that subarachnoid bypass, which effectively evades the blocked portion of the subarachnoid space with a catheter, reduced the increased pressure inside the spinal cord (6).

In a computational study for focal spinal arachnoiditis, Biston et al reported that peak fluid pressures were higher above the obstruction than in the absence of an obstruction. The peak pressures were strongly dependent on the permeability of the obstruction. Elevations in pressure in the subarachnoid space due to arachnoiditis may facilitate fluid flow into the spinal cord, enhancing syrinx formation (2).

Hayashi et al. reported their series including 20 patients using subarachnoid-subarachnoid bypass and achieved good results. We performed same surgical procedure, however we also added syringopleural shunt to decompress the syrinx.

For our patient, using a syringoperiopleural shunt and connecting the cephalic, upper high pressure subarachnoid space to the caudal, lower low pressure subarachnoid space improved the patient's clinical status, decreased the syrinx size, and provided a safe corridor for CSF passage around the spinal cord. Serial follow-up MRI scans were performed to evaluate the syrinx status and showed that the results of the operation were successful.

\section{CONCLUSION}

There is no standardized treatment for severe forms of arachnoid scarring. Providing a corridor for free CSF passage and untethering the spinal cord are almost impossible, even with surgery. A good solution for this may be to open an adhesion and insert a syringopleural shunt with a subarachnoid-subarachnoid bypass using silicon tubes. As this technical note reports the positive results of only one patient, a case series should be performed to validate the results of this one case.

\section{REFERENCES}

1. Aghakhani N, Baussart B, David P, Lacroix C, Benoudiba F, Tadie $M$, Parker F: Surgical treatment of posttraumatic syringomyelia. Neurosurgery 66(6):1120-1127, 2010

2. Bilston LE, Fletcher DF, Stoodley MA: Focal spinal arachnoiditis increases subarachnoid space pressure: A computational study. Clin Biomech (Bristol, Avon) 21(6):579-584, 2006

3. Bonfield CM, Levi AD, Arnold PM, Okonkwo DO: Surgical management of post-traumatic syringomyelia. Spine (Phila Pa 1976) 35(21):245-258, 2010

4. Brodbelt AR, Stoodley MA, Watling AM, Tu J, Burke S, Jones NR: Altered subarachnoid space compliance and fluid flow in an animal model of posttraumatic syringomyelia. Spine (Phila Pa 1976) 28(20):413-419, 2003

5. Cacciola F, Capozza M, Perrini P, Benedetto N, Di Lorenzo N: Syringopleural shunt as a rescue procedure in patients with syringomyelia refractory to restoration of cerebrospinal fluid flow. Neurosurgery 65(3):471-476, 2009

6. Chang HS, Nakagawa H: Theoretical analysis of the pathophysiology of syringomyelia associated with adhesive arachnoiditis. J Neurol Neurosurg Psychiatry 75(5):754-757, 2004

7. Cho KH, Iwasaki $\mathrm{Y}$, Imamura $\mathrm{H}$, Hida $\mathrm{K}$, Abe H: Experimental model of posttraumatic syringomyelia: The role of adhesive arachnoiditis in syrinx formation. J Neurosurg 80(1):133-139, 1994

8. El Masry WS, Biyani A: Incidence, management, and outcome of post-traumatic syringomyelia: In memory of Mr Bernard Williams. J Neurol Neurosurg Psychiatry 60(2):141-146, 1996

9. Falci SP, Indeck C, Lammertse DP: Posttraumatic spinal cord tethering and syringomyelia: Surgical treatment and longterm outcome. J Neurosurg Spine 11(4):445-460, 2009

10. Hayashi T, Ueta T, Kubo M, Maeda T, Shiba K: Subarachnoidsubarachnoid bypass: A new surgical technique for posttraumatic syringomyelia. J Neurosurg Spine 18(4): 382-387, 2013

11. Klekamp J: Treatment of syringomyelia related to nontraumatic arachnoid pathologies of the spinal canal. Neurosurgery 72(3):376-389, 2013 
12. Levi AD, Sonntag VK: Management of posttraumatic syringomyelia using an expansile duraplasty. A case report. Spine (Phila Pa 1976) 23(1):128-132, 1998

13. Small JA, Sheridan PH: Research priorities for syringomyelia: $A$ National Institute of Neurological Disorders and Stroke Workshop summary. Neurology 46:577-582, 1996

14. Tator $\mathrm{CH}$, Meguro K, Rowed DW: Favorable results with syringosubarachnoid shunts for treatment of syringomyelia. J Neurosurg 56(4):517-523, 1982
15. Williams B: Post-traumatic syringomyelia, an update. Paraplegia 28(5):296-313, 1990

16. Wong J, Hemley S, Jones N, Cheng S, Bilston L, Stoodley M: Fluid outflow in a large-animal model of posttraumatic syringomyelia. Neurosurgery 71(2):474-480, 2012 